\title{
Serum Uric Acid in Pre-eclampsia
}

\section{Dr. Yanglem Ajitkumar ${ }^{1}$, Dr. Sangeeta Naorem ${ }^{* 2}$, Dr. Victoria Kshetrimayum ${ }^{3}$, Dr. Yengkhom Upen Singh ${ }^{4}$, Dr. Sneha Saha ${ }^{4}$, Dr. Potsangbam Jenny Devi ${ }^{4}$, Dr. Uma Debbarma ${ }^{4}$, Dr. Maisnam Amuba Singh ${ }^{5}$}

${ }^{1}$ Assistant Professor, Obstetrics and Gynaecology Department, Regional Institute of Medical Sciences (RIMS), Imphal, Manipur, India

${ }^{2}$ Associate Professor, Department of Biochemistry, RIMS, Imphal, Manipur, India

${ }^{3}$ Senior Resident, Department of Biochemistry, RIMS, Imphal, Manipur, India

${ }^{4}$ Post graduate trainee, Department of Biochemistry, RIMS, Imphal, Manipur, India

${ }^{5}$ Professor, Department of Biochemistry, RIMS, Imphal, Manipur, India

*Corresponding author: Dr. Sangeeta Naorem; drsangeetanaorem@gmail.com

Received 19 March 2019;

Accepted 04 April 2019;

Published 12 April 2019

\begin{abstract}
Background: Hypertension in pregnancy is a major cause of maternal death and also a major source of maternal and perinatal morbidity and perinatal morbidity. Hyperuricemia is a common finding in preeclamptic pregnancies. The elevation of uric acid in preeclamtic women often precedes hypertension and proteinuria, the clinical manifestations used to diagnose the disorder. The aim of this study is estimation of serum uric acid in preeclamptic patients. A case-control study was done in the Department of Biochemistry in collaboration with Deptt of Obstetrics \& Gynaecology, Regional Institute Of Medical Sciences (RIMS), Impha(Manipur), India. Methods: Data collected from 50 pre-eclamptic pregnant women and 25 normotensive pregnant women admitted in antenatal ward, Deptt of Obstretics and Gynaecology, RIMS hospital. The blood samples were collected from these patients and analysed for serum uric acid level. Results: The serum uric levels were found to be significantly higher in preeclamptic cases than in normal controls. Mean \pm SD of uric acid was $8.82 \pm 1.68 \mathrm{mg} \%$ in cases compared to $4.06 \pm 0.96 \mathrm{mg} \%$ in the controls. Conclusion: Hyperuricemia can be used as biomarker for identifying women at risk of preeclampsia and its complications with adverse effects
\end{abstract}

Keywords: Uric acid, pre eclampsia, hyperuricemia

\section{Introduction}

Hypertension in pregnancy is a major cause of maternal death and also a major source of maternal and perinatal morbidity and perinatal mortality ${ }^{[1]}$. Preeclampsia is a pregnancy specific syndrome of reduced organ perfusion secondary to vasospasm and endothelial activation. It can be defined as a multisystem disorder of unknown etiology characterized by development of hypertension to the extent of $140 / 90 \mathrm{mmHg}$ or more with proteinuria induced by pregnancy after the 20 th $^{\text {week }}{ }^{[2]}$.

Hyperuricemia is a common finding in preeclamptic pregnancies. The elevation of uric acid in preeclamtic women often precedes hypertension and proteinuria, the clinical manifestations used to diagnose the disorder ${ }^{[3]}$. Outside of pregnancy, hyperuricemia is considered a risk factor for hypertension, cardiovascular and renal disease $^{[4]}$.This evidence, as well as the observation that severity of preeclampsia increases with increasing uric acid, questions whether uric acid may play a role in the pathophysiology of preeclampsia. The association between hyperuricemia with preeclampsia has been known since $1917^{[5]}$.
Uric acid is a component of non-protein nitrogenous substances. A small fraction of urates is loosely bound to plasma proteins. It is the final product of purine metabolism oxidation which is mainly excreted in the urine. It is important to identify women who are high risk of developing the disease early developed nations ${ }^{[6]}$. Since increased uric acid is the first and earliest laboratory presentation of preeclampsia as a result of reduced clearance of uric acid due to decreased glomerular filtration clearance, increases tubular reabsorption, and reduced secretion, some investigators use serum uric acid as criterion for preeclampsia ${ }^{[7]}$.

It has been indicated that uric acid might not only have a predictive role in preeclampsia but also play a significant role in the maternal and fetal pathogenesis and presentations. Some previous investigations mentioned a higher level of uric acid in patients with preeclampsia compared to healthy subjects ${ }^{[8]}$. However, other studies mentioned that a higher level of uric acid levels in preeclampsia might be as a result of associated diseases. They noted no important predictive value for uric acid. ${ }^{[9]}$ This research work aims to evaluate serum uric acid in normal pregnant women and in preeclamptic cases. 


\section{Materials and Methods}

A case control study was conducted to evaluate the level of serum uric acid in preeclamptic patients (cases) and normal pregnant women (controls) in 3rd trimester admitted in the Antenatal ward and labour room in the Deptt. of Obstetrics And Gynaecology. It was done in the Deptt. of Biochemistry in collaboration with the Deptt. of Obstretics And Gynaecology, Regional Institute of Medical Sciences, Imphal during the period from June 2016 to June 2018.

Patients who were diagnosed as preeclampsia were taken as the cases and normal pregnant women of comparable gestational age as controls. Fifty pregnant women in the age group 18-45 years having blood pressure $\geq 140 / 90 \mathrm{mmHg}$ and proteinuria $\geq 300 \mathrm{mg}$ in 24 hours urine collection after 20 weeks of gestation were recruited as preeclamptic cases. Another 25 normal pregnant women of similar age group and gestational age were matched for age, weight and gestational age. All the cases and controls in the study were subjected to detailed history regarding age, parity, height and weight at the time of blood collection. Maternal education, religion, race, socio economic status, menstrual history, obstetric history were taken. General physical examinations and systemic examinations with special referenc to oedema and blood pressure were carried out. And all investigations were recorded in the performa designed for the study. Those patients with pre-existing hypertension, cardiovascular or renal diseases, diabetes mellitus or chronic diseases.

\section{Ethics}

Ethical clearance was obtained from the Ethical Committee, Regional Institute of Medical Sciences, Imphal.

$5 \mathrm{ml}$ of venous blood was drawn from ante cubital vein after an overnite fast. The sample was centrifuged for 10 minutes and analysed for serum uric acid in the Department of Biochemistry, RIMS. Serum uric acid was analysed by Uricase method (enzymatic colorometric test) modified by Human Co., Germany $^{[10,11]}$.

\section{Statistical analysis}

After thorough checking and scrutinizing, the data were processed through computer with statistical software using SPSS-16 version. Statistical formulae like Chi-Square-test, independent sample ttest; Pearson correlation coefficient " $r$ ", degree of freedom(Df) were used wherever found suitable and necessary and accordingly interpretations were made.

\section{Results and observations}

Table 1: Distribution of case and control group according to religion

\begin{tabular}{|l|c|c|c|}
\hline Religion & \multicolumn{2}{|c|}{ Group } & Total \\
\hline & $\begin{array}{c}\text { Control group } \\
\text { no. (\%) }\end{array}$ & $\begin{array}{c}\text { Case group } \\
\text { no. }(\%)\end{array}$ & \\
\hline Hindu & $19(76)$ & $35(70)$ & 54 \\
\hline Muslim & $3(12)$ & $3(20)$ & 13 \\
\hline Christian & $3(12)$ & $5(10)$ & 8 \\
\hline Total & $25(100)$ & $50(100)$ & 75 \\
\hline
\end{tabular}

$X^{2}=4.344 ; d f=2 ; p=0.114$
Table-1 shows the distribution of preeclampsia women and normal pregnant women among the various religious groups. The majority of women in the case group were Hindus (70\%) whereas Muslims and Christian comprised of $20 \%$ and $10 \%$ respectively. In the control group Hindus comprises of $76 \%$ whereas Muslims and Christians comprises of $12 \%$ each. It was found that there was no significant difference $(\mathrm{p}=0.683)$ observed between them.

Table 2: Distribution of case and control group according to socioeconomic status

\begin{tabular}{|l|l|l|l|}
\hline & \multicolumn{2}{|c|}{ Group } & Total \\
\hline $\begin{array}{c}\text { Socio economic } \\
\text { status }\end{array}$ & $\begin{array}{c}\text { Control group } \\
\text { no. }(\boldsymbol{\%})\end{array}$ & $\begin{array}{c}\text { Case control } \\
\text { no. }(\boldsymbol{\%})\end{array}$ & \\
\hline High & $7(28)$ & $6(12)$ & 13 \\
\hline Medium & $3(12)$ & $14(28)$ & 17 \\
\hline Low & $15(60)$ & $30(60)$ & 45 \\
\hline Total & $25(100)$ & $50(100)$ & 75 \\
\hline
\end{tabular}

$\mathrm{X} 2=0.761 ; \mathrm{df}=2 ; \mathrm{p}=0.683 \mathrm{df}=$ Degree of Freedom

Table- 2 shows that majority of the women in the case group belong to the lowest socioeconomic group (60\%) followed by women belonging to medium (28\%) and high economic status (12\%) respectively. The pattern was found to exist in both the groups and no significant difference $(\mathrm{p}=0.114)$ was observed.

Table 3: Distribution of case and control group according to parity

\begin{tabular}{|l|c|c|c|}
\hline \multicolumn{3}{|c|}{ Group } & \\
\hline Parity & $\begin{array}{c}\text { Control group } \\
\text { no. (\%) }\end{array}$ & $\begin{array}{c}\text { Case group } \\
\text { no. (\%) }\end{array}$ & Total \\
\hline $\mathrm{P}_{0+0}$ & $15(60)$ & $25(50)$ & 40 \\
\hline $\mathrm{P}_{1+0}$ & $3(12)$ & $10(20)$ & 13 \\
\hline $\mathrm{P}_{2+0}$ & $4(16)$ & $10(20)$ & 14 \\
\hline $\mathrm{P}_{3}$ and above & $3(12)$ & $5(10)$ & 8 \\
\hline Total & $25(100)$ & $50(100)$ & 7.5 \\
\hline
\end{tabular}

$X^{2}=1.130 ; d f=3 ; p=0.769$

Table-3 shows the distribution of controls and cases according to parity. It was seen that maximum number of cases $(50 \%)$ occur in primiparas $\left(\mathrm{P}_{0+0}\right), 20 \%$ belong to ${ }_{\mathrm{P} 1+0}, 20 \%$ belong to $\mathrm{P}_{2+0}$ and $10 \%$ belong to $\mathrm{P}_{3}$ and above. Insignificant value of $\chi^{2}=1.130 ; \mathrm{p}=0.769$ suggests that parity is matched between the groups

Table 4: Distribution of case and control group according to the age group

\begin{tabular}{|l|c|c|}
\hline Group & No. of patients & Mean \pm SD (Years) \\
\hline Control group & 25 & $27.64 \pm 4.6$ \\
\hline Case group & 50 & $26.50 \pm 5.50$ \\
\hline
\end{tabular}

SD: Standard Deviation; $t=0.883 ; d f=73 ; p=0.380$

It is evident from Table- 4 that maximum number of the cases occured in the age group of 21-25 years. The women in control group had older age than that of the case group. However the difference was found to be insignificant at 5\% probability level.

Table 5: Distribution of case and controls according to complications

\begin{tabular}{|l|c|c|c|}
\hline \multicolumn{1}{|c|}{ Complications } & \multicolumn{2}{c|}{ Group } & Total \\
\hline & $\begin{array}{c}\text { Control } \\
\text { group (\%) }\end{array}$ & $\begin{array}{c}\text { Case } \\
\text { group (\%) }\end{array}$ & \\
\hline Abruptio placentae & 0 & $1(2)$ & 1 \\
\hline Congenital malformation & 0 & $1(2)$ & 1 \\
\hline Intrauterine fetal death & 0 & $4(8)$ & 4 \\
\hline
\end{tabular}




\begin{tabular}{|l|l|l|l|}
\hline No complication & $25(100)$ & $44(88)$ & 69 \\
\hline Total & $25(100)$ & $50(88)$ & 75 \\
\hline
\end{tabular}

It is evident from Table- 5 that out of the 50 preeclamptic patients, $88 \%$ cases have no complications whilst $8 \%$ have intrauterine foetal dead (IUFD), $2 \%$ has abruptio placentae and $2 \%$ has congenital malformation. In the control group none has complications. The complications that occurred within the case group is found to be highly significant compared to normal pregnant controls $(\mathrm{p}<0.001)$.

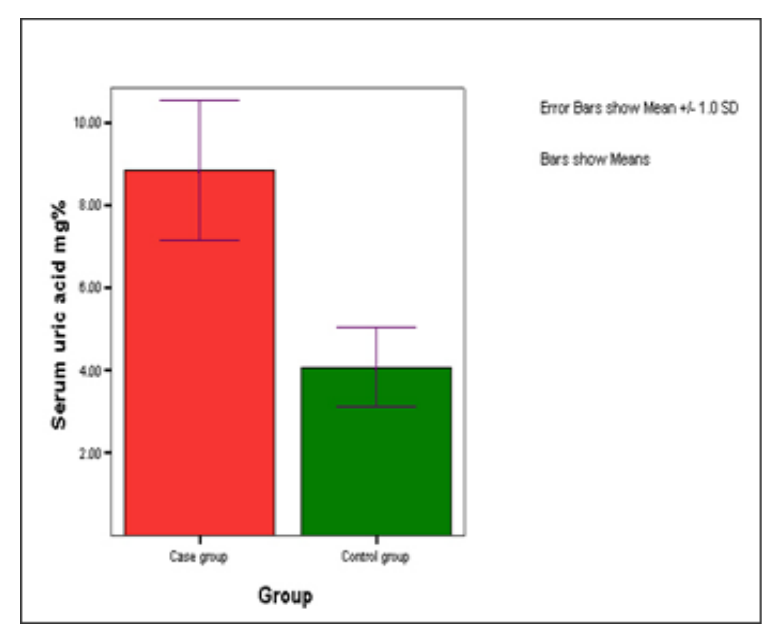

Fig. I: Comparison of mean \pm SD of serum uric acid (mg \%) between the case and control group

Fig. I shows that the serum uric acid levels in the cases are higher than the controls. The mean $\pm \mathrm{SD}(\mathrm{mg} \%)$ for the cases is $8.82 \pm 1.68$ whereas in the control group it is $4.06 \pm 0.96$. This difference in the values is very highly significant $(p=0.000)$.

\section{Discussion}

The study shows that majority of the patients were Hindus (70\%) followed by Muslims (20\%) and Christians (10\%) as shown in Table-1. This pattern is observed was both the cases and controls and no significant difference $(p=0.683$ ) was found between them. The reason may be due the fact that the study was being conducted in the Hindu dominated area. In the case of socioeconomic status, women in the lowest status $(60 \%)$ have the highest frequency followed by medium class (28\%) and least number of cases belonged to high socioeconomic class (12\%) as shown in Table-2. The pattern was found to exist in both groups and no significant difference $(p=0.114)$ is observed between the groups. Our findings are almost similar to the study of Punam $D$ et al ${ }^{[12]}$ where they showed maximum number of preeclamptic women belonged to lower socioeconomic status $(56 \%)$, followed by middle class(23\%) and higher status(21\%) which was statistically significant. Another study by Kanak KM et $\mathrm{al}^{[13]}$ also found the same result as our study.

Maximum number of cases was observed in the primigravida $(50 \%)$ and only $10 \%$ of the cases were seen above third gravida (Table-3).The finding was similar to Ingec $\mathrm{M}$ et $\mathrm{al}^{[14]}$ who have also reported that preeclampsia occurs more commonly in primiparas compared to normal controls.

In the present study maximum numbers of preeclamptic cases occur in the age group of 21-25 years (59\%) and only $10 \%$ occurs at 36 years and above (Table-4).The women in the control group are older than women in the case group. However, the difference is found to be insignificant at $5 \%$ probability level. Table-5 shows that the mean age \pm SD of the cases is $26.50 \pm 5.50$ years. This finding is similar to the finding of Powers $\mathrm{W}$ et $\mathrm{al}^{[15]}$ who found the mean age \pm SD to be $26.2 \pm 5.8$ years.

The study shows that out of the 50 preeclamptic cases, $44(88 \%)$ cases have no complications, one case (2\%) delivered a baby with congenital malformation, one case $(2 \%)$ has abruptio placentae and another $8 \%$ have intrauterine foetal death. No complication was seen in the control group. The difference in complication between the cases and controls was highly significant $(\mathrm{p}=0.001)$.

The serum uric acid in the cases is higher than the controls. Mean \pm $\mathrm{SD}$ in the case group is $8.82 \pm 1.68 \mathrm{mg} \%$ compared to $4.06 \pm 0.96$ $\mathrm{mg} \%$ in the controls. The difference in the values between the study groups is highly significant. It has been reported that rise in uric acid level in preeclampsia is secondary to placental damage leading to purine catabolism and production of uric acid.

In normal pregnancy, serum uric acid level slowly decrease until about 16 weeks of gestation, secondary to plasma volume expansion, increased renal clearance, and the uricosuric effect of estrogen. For most of the 2nd trimester, the uric acid level remains stable, and then increases during the 3 rd trimester ${ }^{[16]}$. Interestingly, women with a history of preeclampsia also have higher risk for cardiovascular disease and hypertension later in life ${ }^{[17,18]}$. Uric acid is minimally soluble and its concentrations is maintained relatively low in healthy individuals $(<6.0 \mathrm{mg} / \mathrm{dL})$. However even low concentrations of uric acid posses biological function. The thirdtrimester rise in uric acid may be related to an increase in foetal uric acid production or a decrease in uric acid clearance ${ }^{[19]}$. Elevated serum uric acid levels due to decreased renal urate excretion are frequently found in women with preeclampsia ${ }^{[20]}$. Soluble uric acid impairs nitric oxide generation in endothelial cells inducing endothelial dysfunction ${ }^{[21]}$. Besides the reduced clearance hyperuricemia in pre-eclampsia may be due to increased uric acid production caused by trophoblast breakdown, cytokine release and ischaemia. Their increased levels might have led to endothelial dysfunction which eventually results in preeclampsia. So, preeclampsia, which is characterized by widespread endothelial dysfunction and inflammation, might be propagated by uric $\operatorname{acid}^{[22]}$. It has also been reported that rise in uric acid level in preeclampsia is secondary to placental damage leading to purine catabolism and production of uric acid.

\section{Conclusion}

The results of this study confirm the hypothesis that hyperuricemia is correlated with preeclampsia being indirect risk factors for placental vasculopathy predating clinical preeclampsia. Thus it can be concluded that hyperuricemia can be used as biomarker for identifying women at risk of preeclampsia and its complications with adverse effects.

Several potential limitations of our study are worth mentioning. All the cases were preeclamptic before the measurement of serum uric acid level and, so it cannot be determined whether the observed elevation in uric acid preceded the development of preeclampsia. Hyperuricemia in preeclampsia patients need to be confirmed in a design in which uric acid is measured before the development of preeclampsia or early pregnancy in order to identify and monitor the patients at risk and thus provide the best prenatal care for these women and their babies. 


\section{References}

[1] Stander H, Cadden J: Blood chemistry in preeclampsia and eclampsia, American Journal Obstetric Gynecology .1934; 28: 856-871.

[2] Chesley LC: Diagnosis of preeclampsia .Obstet. \&Gynaec.1985; 65:423.

[3] Powers RW, Bodnar LM, Ness RB, Cooper KM, Gallaher MJ, Frank MP, Daftary AR, Roberts JM. Uric acid concentrations in early pregnancy among preeclamptic women gestational hyperuricemia at delivery. Am J Obstet Gynecol. 2006;194:160[PubMed:16389026]

[4] Johnson RJ, Kang DH, Feig D, Kivlighn S, Kanellis J, Watanabe S, Tuttle KR, Rodriguez-Iturbe B, HerreraAcosta J, Mazzali M. Is there pathogenictic role for uric acid in hypertension and cardiovascular and renal disease? Hypertension. 2003;41:1183-90[PubMed: 12707287]

[5] Kang D, Finch J, Nakagawa $\mathrm{T}$ et al: Uric acid, endothelial dysfunction and pre-eclampsia: searching for a pathogenetic linl. J Hypertension 2004; 22:229-235.

[6] Watanabe S, Kang DH, Feng L, et al: Uric acid, hominoid evolution, and the pathogenesis of saltsensitivity. Hypertension 2002; 40:355-360.

[7] Burrow, Duffy \& Copel: Medical complications during pregnancy 2004;6th edition

[8] Livingston JR PB, Brown M, Roberts JM, Cote AM, Magee LA, von Dadelszen P. Uric Acid as a predictor of adverse maternal and perinatal outcomes in women hospitalized with preeclampsia. J Obstet Gynaecol Can 2014;36:870-877

[9] Marvel P, Bar, Beaufils M, et al: Lone hyperuricemia during pregnancy, Maternal and fetal outcomes. Eur J Obstet Gynecol Reprod Bio 1998; 177:145-150.

[10] Simic M, Jovanovic S. Antioxidants mechanisms of uric acid. J Am Chem Soc. 1989; 111:5778-5782.

[11] Mazzali M, Hughes J, Kim YG, et al: Elevated uric acid increases blood pressure in the rat by a novel crystal- independent mechanism. Hypertension 2001;38:11011106

[12] Johnson RJ, kang DH, Feig D: Is there a pathogenic role for uric acid in hypertension and cardiovascular and renal disease? 3003;41:1183-1190.

[13] Barham D, Trinder P. An improved colour reagent for the determination of blood glucose by oxidase system. Analyst 1972;97(151):142-45.

[14] Fossati P, Prencipe L, Berti G.Use of 3,5-dichloro-2hydroxybenzesulfonic acid/ 4-aminophenazone chromogenic system in direct enzymatic assay of uric acid in serum and urine. Clin Chem 1980;26(2):227-31.

[15] Punam D, Sachdeva PD, Patel BG, Bhatt MV et al. A study of incidence and management of pregnancy induced hypertension in central Gujarat, India. Int J Univ Pharmacy Life Sci 2011 Nov-Dec;1(3):61-70.

[16] Kanak KM, Premchandra YS, Aripta D, Sangeeta N, Nabakishore NS, Gyaneshwar WS. Serum uric acid and c-reactive protein in preeclampsia. IOSR-JDMS 2015;14(2):16-23

[17] Ingec M, Borekci B, Kadanali S. Elevated plasma homosysteine concentrations in severe eclampsia and preeclampsia, Tohoku J Exp Med 2001;201:225-31.

[18] Powers RW, Dunbar MS, Laivuori HM, Harger GF, Lykins DL and Roberts JM. Maternal plasma homocysteine concentrations are not increased in twin pregnancies, Hypertens Pregnancy 2005; 24:49-58.

[19] Dunlop W, Davison JM(1977) The effect of normal pregnancy upon the renal handling of uric acid . Br J Obstet Gynaecol 84:13-21.

[20] Kang DH, Finch J, Nakagawa T, Karumanchi SA, Kanellis J, et al(2004) Uric acid, endothelial dysfunction and pre-eclampsia searching for a pathogenic link. J Hupertens 22:229-35

[21] Khosla UM, Zharikov S, Finch JL, Nakagawa T, Roncal $C$, et al.(2005) Hyperuricemia induces endothelial dysfunction. Kidney Int 67:1739-42.

[22] Martin AC, Brown MA (2010) Could uric acid have a pathogenic role in preeclampsia? Nat Rev Nephrol 6:744-8. 